\title{
ASPECTOS IMPORTANTES DA DISSOLUÇÃO DA SOCIEDADE CONJUGAL ENTRE OS CÔNJUGES OU DO VÍNCULO MATRIMONIAL PELO DIVÓRCIO OU PELA MORTE
}

\author{
Monaliza Costa de Souza ${ }^{1}$
}

\section{INTRODUÇÃO}

Muitos são os assuntos do Direito de Família que são tratados em artigos ou apresentados em congressos, porém somente sobre uma ótica específica, e não uma análise do todo, que é o que se propõe no presente estudo a respeito da dissolução do vínculo conjugal. Numa avaliação da completude do assunto, é possível clarificar as demais discussões a respeito das questões específicas.

Dissolver a sociedade conjugal é basicamente o afastamento físico do casal, do regime de bens, mas persiste a manutenção do vínculo do matrimônio. Atualmente, a legislação facilitou à sociedade o término dos relacionamentos, excluindo da Constituição o prazo para divórcio. As novidades no direito de família resultam de um longo processo de desenvolvimento humano, é um resultado das necessidades dos cidadãos.

Estudar a dissolução do vínculo matrimonial faz parte de um processo de aprendizado e aprimoramento dos indivíduos como pessoas e profissionais envolvidos num processo duro de ruptura relacional. Assim, propõe-se avaliar passado e presente para a

1 Advogada e mediadora. Mestre em Direito pela Universidade Federal do Rio Grande do Sul (2013). Especialista em Direito de Família Contemporâneo e Mediação pela FADERGS (2012). Graduada em Direito pelo Centro Universitário do Distrito Federal (2006). Membro da Associação Brasileira Criança Feliz. Membro do grupo de pesquisa “Direitos Fundamentais Civis: A Ampliação dos Direitos Subjetivos” da UNOESC. Foi conciliadora do Tribunal de Justiça do Distrito Federal e Territórios. 
construção do entendimento de como se dá o fim do casamento.

Para isso são utilizadas doutrinas clássicas e modernas que auxiliarão na compreensão do tema.

\section{DIFERENÇA ENTRE DISSOLUÇÃO DA SOCIEDADE E DO VÍNCULO CONJUGAL}

Ao falar em dissolução do casamento, apesar de logo se pensar em separação e divórcio, não é tão objetivo quanto parece. Alguns pontos são importantes para a compreensão do assunto e o primeiro deles é a distinção entre sociedade e vínculo conjugal.

O casamento tem, no Código Civil, expressão através dos artigos 1.511 a 1.590. Sendo que vale, neste momento, destacar o disposto no artigo 1.514: "O casamento se realiza no instante em que o homem e a mulher manifestam, perante o juiz, a sua vontade de estabelecer vínculo conjugal, e o juiz os declara casados".

Pois bem, o casamento estabelece “vínculo conjugal”. Através dele os consortes assumem a responsabilidade pelos encargos da família (artigo 1.565 do Código Civil) e passam a ter alguns deveres que vêm mencionados no texto do artigo 1.566 do Código Civil, quais sejam: “(I) fidelidade recíproca; (II) vida em comum, no domicílio conjugal; (III) mútua assistência; (IV) sustento, guarda e educação dos filhos; (V) respeito e consideração mútuos".

É no artigo 1.567, também do diploma legal civil, que se encontra o termo "sociedade conjugal”, que tem direção exercida pelos cônjuges de forma colaborativa em prol do casal e dos filhos, se houverem.

Nos termos acima, não é simples estabelecer qual a diferença entre vínculo e sociedade conjugal. Através da leitura dos artigos do Código Civil destacados anteriormente, é possível determinar como ponto de partida que o "vínculo conjugal” tem início com o casamento e fim com o divórcio ou a morte de um dos consortes. Convém, portanto, verificar o que a doutrina diz a respeito, e sobre isso Maria Helena Diniz ${ }^{2}$ diz que:

O casamento é, sem dúvida, um instituto mais amplo que a sociedade conjugal, por regular a vida dos consortes, suas relações e suas obrigações recíprocas, tanto as morais como as materiais, e seus deveres para com a família e a prole. A sociedade conjugal, embora contida no matrimônio, é um instituto jurídico menor do que

2 DINIZ, Maria Helena. Curso de direito civil brasileiro. Volume 5. direito de família. 25. ed. São Paulo: Saraiva, 2010, p. 249. 
o casamento, regendo, apenas, o regime matrimonial de bens dos cônjuges, os frutos civis do trabalho ou indústria de ambos os consortes ou de cada um deles. Daí não se poder confundir o vínculo matrimonial com a sociedade conjugal.

Nesse sentido, falar em dissolução da sociedade conjugal é falar no momento em que finda o regime de bens de um casamento, bem como o dever de coabitação e de fidelidade recíproca, como coloca o artigo 1.576 do Código Civil.

Por óbvio, se o vínculo conjugal é maior que a sociedade, com o seu término também tem fim o regime de bens do casamento. Porém, com o fim da sociedade conjugal, ainda é possível que o vínculo matrimonial permaneça e com ele a impossibilidade de estabelecimento de novo casamento. Paulo Nader ${ }^{3}$ completa esse entendimento falando da permanência dos deveres de mútua assistência, respeito e consideração mútuos, sustento, guarda e educação dos filhos, mas isso parece um pouco frágil, na medida em que a mútua assistência pode permanecer mesmo com o fim do vínculo, como o próprio autor excetua, e o sustento, guarda e educação dos filhos seguem além da dissolução do vínculo conjugal. Diz o autor que:

Com a celebração do casamento nascem o vínculo e a sociedade conjugal. Aquele é a relação jurídica que se instaura entre os cônjuges, enquanto a sociedade é o compromisso de comunhão de vida. Dissolvendo-se o vínculo, extingue-se a sociedade conjugal. O término desta não põe termo àquele, apenas aos deveres de coabitação, fidelidade recíproca e ao regime de bens, conforme dispõe o art. 1.576 do Código Civil. Por força do vínculo conjugal permanecem os deveres de mútua assistência, respeito e consideração entre os separados, além do sustento, guarda e educação dos filhos. A permanência da mútua assistência entre os deveres há de ser interpretada em termos, pois limitada a alimentos. Em decorrência, ainda, da subsistência do vínculo, os separados ficam impedidos de contrair novo casamento. $\mathrm{O}$ vínculo conjugal dissolve-se, no casamento válido, com a morte real ou presumida de um dos cônjuges, declaração judicial de ausência ou pelo divórcio. ${ }^{4}$

Conclui-se, então, o raciocínio, com a simples, porém elucidativa, explicação de Pontes de Miranda ${ }^{5}$, que

3 NADER, Paulo. Curso de direito civil brasileiro. Volume 5. direito de família. Rio de Janeiro: Forense, 2006, p. 243-244.

4 NADER, Paulo. Curso de direito civil brasileiro. Volume 5. direito de família. Rio de Janeiro: Forense, 2006, p. 243-244.

5 PONTES DE MIRANDA, Tratado de direito de família. V. 1. Atualizado por Vilson Rodrigues Alves. Campinas: Bookseller, 2001, p 403. 
diz que: “[...] É preciso, porém, não se confundirem vínculo conjugal, que só se dissolve com a morte ou com o divórcio, e a sociedade conjugal, que é o fato da vida em comum no domicílio conjugal.”

Assim, e com base no artigo 1.571 do Código Civil, a dissolução da sociedade conjugal se dá: (I) pela morte (real ou presumida) de um dos cônjuges; (II) pela nulidade ou anulação do casamento; (III) pela separação judicial (embora haja controvérsias a respeito); e (IV) pelo divórcio. Mas a dissolução do vínculo, que é definitiva, somente acaba pela morte ou pelo divórcio.

\section{BREVE HISTÓRICO}

A história desenvolvida entre a instituição do casamento, a sua indis- solubilidade e o estabelecimento do divórcio, sem requisitos, no ordenamento jurídico, elucida uma evolução da própria sociedade.

Sabe-se que apesar de a Igreja Católica afirmar que o sacramento do matrimônio é uma instituição divina, advinda da Criação ${ }^{6}$, conforme Sílvio de Salvo Venosa ${ }^{7}$ afirma, foi no Concílio de Trento que ele foi consagrado como tal (dogma do sacramento do matrimônio), nos idos de 1563, quando também foi declarado como vínculo indissolúvel. O autor também completa que foi no século XVIII que o casamento civil foi implementado, mantendo, porém, sua estrutura canônica.

Através dos tempos, foi possível verificar a grande influência da Igreja na condução da vida em sociedade. ${ }^{8}$ Por muitos anos essa influência orientou as questões jurídicas, e só

6 Artigo $7^{\circ} \S \S 1601$ e 1602 do Catecismo da Igreja Católica. Disponível em: <http:// www.vatican.va/archive/cathechism_po/index_new/p2s2cap3_1533-1666_po.html> Acesso em: 21 abr. 2011.

7 VENOSA, Sílvio de Salvo. Direito civil. V. 6: direito de família. 11. ed. São Paulo: Atlas, 2011, p. 158.

8 "Desde a colonização portuguesa até 1977 prevaleceu a indissolubilidade do casamento, projetando-se no direito civil a concepção canônica da Igreja Católica de ser o matrimônio instituição de natureza divina, que jamais poderia ser dissolvido por ato dos cônjuges. Nem mesmo a separação entre Estado e a Igreja, com o advento da República, foi suficiente para secularizar a desconstituição do casamento, que sofreu forte resistência das organizações religiosas católicas.

[...]Após a República, que separou a Igreja do Estado e instituiu o casamento civil, o Decreto 521, de 1890, apenas previu a separação de corpos, sem dissolução do vínculo matrimonial” (LÔBO, Paulo. Direito civil: famílias. 4. ed. São Paulo: Saraiva, 2011, p. 149, grifou-se). 
hoje, aos poucos, é que se tem como principal objetivo o atendimento das necessidades dos cidadãos. Tanto é que a indissolubilidade do casamento resistiu por muito tempo até que se pudesse chegar à possibilidade de dissolução diretamente através do divórcio, sem qualquer prazo, como atualmente é possível.

Paulo Lôbo completa dizendo que:

No regime anterior à República, a sociedade conjugal apenas terminava pela morte de um dos cônjuges, pela entrada de um deles em ordens sacras maiores, pela nulidade, pelo divórcio perpétuo de fonte canônica, mas sem dissolução do casamento. Decreto de 1827 determinava a observância das disposições do Concílio de Trento e da Constituição do Arcebispo da Bahia. Após a República, que separou a Igreja do Estado e instituiu o casamento civil, o Decreto 521, de 1890, apenas previu a separação de corpos, sem dissolução do vínculo matrimonial. ${ }^{9}$ (grifou-se.)

Com isso, percebe-se que a evolução foi lenta mesmo após estabelecimento da laicidade do Estado Brasileiro pelo Marechal Manoel Deodoro da Fonseca, em 7 de janeiro de
1890, através do Decreto ${ }^{\circ} 119-\mathrm{A}$, e a liberdade de culto, posteriormente consolidada na Constituição de 1891, através de disposições do artigo 72. Ainda assim permaneceu a influência da Igreja Católica no país. Apesar de o Brasil continuar sob influência católica, tais mudanças podem ser consideradas como um grande marco determinante às decisões legislativas. Hoje se pode dizer que isso viabilizou ao legislador determinar as normas de acordo com aquilo que melhor atende aos interesses dos cidadãos, independente de suas crenças.

Outro ponto importante a se destacar é o que Pontes de Miranda ${ }^{10}$ conta em seu livro Tratado de Direito de Família, em que diz que na história do Direito o divórcio já vinha como uma realidade em Roma. Apesar de pouco mencionado, tal fato importa à evolução divorcista no Brasil, que teve influência direta do direito romano-germânica. De acordo com o autor:

Durante séculos, teve a Igreja de transigir com o divórcio. O direito romano do Alto-Império conhecia três causas de dissolução do casamento: a morte, o divórcio e a escravização. Não se exigia a intervenção do juiz. Também nos costumes germânicos

9 LÔBO, Paulo. Direito civil: famílias. 4. ed. São Paulo: Saraiva, 2011, p. 149.

10 PONTES DE MIRANDA, Tratado de direito de família. V. 1. Atualizado por Vilson Rodrigues Alves. Campinas: Bookseller, 2001, p. 443. 
encontrou a Igreja o divórcio, com o repúdio livre e sem causa justificada, cabendo, quando muito, composição aos parentes, pois que a mulher repudiada a esses voltava. Entre eles, a catividade dissolvia o casamento. E é de notar-se que os reis cristãos, reagindo contra tal direito, mais se preocuparam com a sistematização, na esteira do propósito cristão de igualdade do homem e mulher. Foi dos Romanos que os costumes germânicos receberam o divórcio mútuo consentimento. Compreende-se que, em contato com tais povos, tenha sido renhida a luta da Igreja, tanto mais quanto, dentro dela, havia quem procurasse fundar no Evangelho o divórcio, pelo menos em casos de adultério. Em verdade, porém, o princípio da indissolubilidade ficou ligado à legislação e à jurisdição da Igreja católica sobre o casamento, embora contra a tradição passada. (grifou-se.)

Isso apenas reafirma o fato de os dogmas da Igreja, com grande impacto na sociedade, terem sido o grande freio ao advento do divórcio como fim completo do vínculo conjugal.

Veja-se, então, as formas como o vínculo matrimonial pode ser extinto.

\section{AS FORMAS DE DISSOLUÇÃO DO VÍNCULO CONJUGAL (OU MATRIMONIAL)}

As formas de dissolução da sociedade e do vínculo conjugal encon- tram-se no texto do artigo 1.571 do Código Civil, in verbis:

Art. 1.571. A sociedade conjugal termina:

I - pela morte de um dos cônjuges;

II - pela nulidade ou anulação do casamento;

III - pela separação judicial;

IV - pelo divórcio.

$\S 1^{\circ} \mathbf{O}$ casamento válido só se dissolve pela morte de um dos cônjuges ou pelo divórcio, aplicando-se a presunção estabelecida neste Código quanto ao ausente.

$\S 2^{\circ}$ Dissolvido o casamento pelo divórcio direto ou por conversão, o cônjuge poderá manter o nome de casado; salvo, no segundo caso, dispondo em contrário a sentença de separação judicial. (grifou-se.)

Apesar de ter igual importância uma análise sobre as demais formas de dissolução da sociedade, como as causas de invalidade do casamento, a análise a seguir ficará restrita aos incisos I, III e IV do mencionado artigo, pois a pesquisa vem descrevendo as formas de dissolução do vínculo, que necessariamente precisam passar por uma análise da separação, que era um dos pré-requisitos para a concessão do divórcio.

Pois bem, o fim do casamento, conforme visto, ocorre essencialmente com a morte ou o divórcio, e é dentro deste que cabe falar em fim da sociedade através da separação, a qual ainda se vê a doutrina discorren- 
do sobre a sua permanência no mundo jurídico ou o seu fim.

\subsection{Pela morte de um dos cônjuges}

A morte é elemento determinante para que o cônjuge sobrevivo adquira o estado civil de viúvo(a), o que traz consigo alguns efeitos, quais sejam: (1) a possibilidade de escolher se permanece ou não com o nome de casado; (2) a condição de herdeiro (nos termos do direito sucessório); e (3) o fim do impedimento para casar, com a ressalva de que à mulher a possibilidade seria após 10 meses de viuvez, exceto se nesse período ela der à luz a algum filho ou provar a inexistência de gravidez. ${ }^{11}$ A respeito disso Pontes de Miranda ${ }^{12}$ escreve:

[...] Se o cônjuge morto é a mulher, pode o marido imediatamente contrair novas núpcias; se o morto é o marido, a viúva só se pode casar após dez meses depois do começo da viuvez, salvo se, antes de terminado o referido prazo, dá à luz a algum filho (Código Civil, art. 183, XIV). Quanto aos bens, cessa, com a morte de um dos cônjuges, a comunhão, se há, cabendo ao sobrevivente a metade dos bens comuns, pois que era sua, e a outra metade aos herdeiros do defunto. (grifou-se.)

Tais efeitos não são complicados de se compreender no momento em que se pensa que não houve qualquer questão que ensejasse a dissolução exceto a fatalidade da morte. Entretanto, o item 3 merece especial atenção, pois trata-se de causa suspensiva ao novo casamento (artigo 1.523, inciso II, do Código Civil), que se baseia no interesse da prole do casamento anterior, a fim de que não haja confusão sanguínea ou patrimonial. ${ }^{13} \mathrm{O}$ filho nascido durante a constância do novo casamento, de pai falecido, poderia ficar prejudicado no que concerne à sua condição de herdeiro e sua identidade paterna. Para Maria Berenice Dias ${ }^{14}$, tal efeito da viuvez decorre da presunção dos filhos concebidos na constância do casamento (artigo 1.597, inciso II, do Código Civil), mas não se deve deixar de considerar que a atualidade,

11 DINIZ, Maria Helena. Curso de direito civil brasileiro. Volume 5: direito de família. 25. ed. São Paulo: Saraiva, 2010, p. xxx.

12 PONTES DE MIRANDA, Tratado de direito de família. V. 1. Atualizado por Vilson Rodrigues Alves. Campinas: Bookseller, 2001, p. 403-404.

13 DINIZ, Maria Helena. Curso de direito civil brasileiro. Volume 5: direito de família. 25. ed. São Paulo: Saraiva, 2010, p. 80.

14 DIAS, Maria Berenice. Manual de direito das famílias. 7. ed. rev., atual. e ampl. São Paulo: Editora Revista dos Tribunais, 2010, p. 296. 
moderna em sua tecnologia, conta com testes de gravidez e exames de DNA sofisticados que comprovam, sem maiores problemas, a filiação, tornando possível sanar tal impedimento.

De outro modo, a morte presumida como causa de dissolução da sociedade conjugal é novidade no Código Civil de 2002 ${ }^{15}$, em seu artigo 1.571, parágrafo primeiro, também com respaldo dos artigos $6^{\circ}$ e $7^{016}$, e que permite, inclusive, a instrução do processo de habilitação de novo casamento sob tal fundamento. Antes do novo Código, o consorte do ausente ficava impedido de casar novamente, o que Sílvio Rodrigues concorda ser um inconveniente, mas caracterizador do sistema antidivorcista da época (até por volta de 1977 , quando a sociedade começou a se abrir e veio a Lei do Di- vórcio n. 6.515, de 26 de dezembro de 1977). Para o autor, a dificuldade da lei é a falta de disposição a respeito de um eventual casamento do "viúvo". ${ }^{17}$

Conforme Sílvio Rodrigues, essa é uma questão delicada, da morte presumida, porque:

O problema a ser enfrentado, todavia, decorre do fato de que a lei não cuida, ao contrário do que fazem os Códigos alemão e italiano, dos efeitos advenientes do retorno do presumido morto, quando o aparente viúvo tenha contraído novas núpcias. A dificuldade concentrase na verificação de qual dos dois casamentos deverá ser considerado válido diante do silêncio do Código a respeito, e será oportunamente estudada por ocasião do exame da ausência. ${ }^{18}$ (grifou-se.)

15 Não se deve confundir a existência da "morte presumida" com a possibilidade dela dissolver a sociedade conjugal. A morte presumida já existia no Código Civil de 1916 por via do artigo 10 .

16 Código Civil de 2002: “Art. $6^{\circ}$ A existência da pessoa natural termina com a morte; presume-se esta, quanto aos ausentes, nos casos em que a lei autoriza a abertura de sucessão definitiva.

Art. $7^{\circ}$ Pode ser declarada a morte presumida, sem decretação de ausência: I - se for extremamente provável a morte de quem estava em perigo de vida;

II - se alguém, desaparecido em campanha ou feito prisioneiro, não for encontrado até dois anos após o término da guerra.

Parágrafo único. A declaração da morte presumida, nesses casos, somente poderá ser requerida depois de esgotadas as buscas e averiguações, devendo a sentença fixar a data provável do falecimento."

17 RODRIGUES, Sílvio. Direito civil: direito de família: volume 6. 28. ed. rev. e atual. por Francisco José Cahali, de acordo com o novo Código Civil (Lei n. 10.406, de 10/01/2002). São Paulo: Saraiva, 2008, p. 202 e 431.

18 RODRIGUES, Sílvio. Direito civil: direito de família: volume 6. 28 ed. rev. e atual. por Francisco José Cahali, de acordo com o novo Código Civil (Lei n. 10.406, de 10/01/2002). São Paulo: Saraiva, 2008, p. 202. 
De acordo com o autor, em outros países, como Suíça, Itália e Alemanha, a codificação civil já determina o que deverá ser feito, em contrapartida ao campo aberto a que o Direito brasileiro fica suscetível. Na Itália, por exemplo, declarada a morte presumida do ausente, seu cônjuge poderia se casar novamente, mas no caso do seu reaparecimento o casamento é nulo, mesmo até ali tendo gerado efeitos normalmente, como num casamento putativo. Contudo, se verificada a morte do ausente, o novo casamento permanece válido. Diferente do que ocorre na Alemanha, em que o novo casamento dissolve o antigo, e cujo novo só será anulado por vontade dos atuais cônjuges antes de se ter notícia da sobrevivência do ausente. Para Sílvio Rodrigues, a solução alemã é a mais acertada, porque sai do campo jurídico para o fático, ou seja, mantém o casamento novo em face de vínculo de ligação que há muito fora desfeito. ${ }^{19}$

A preocupação de Sílvio Rodrigues não é isolada, também fala a respeito Sílvio de Salvo Venosa ${ }^{20}$, res- saltando que é questão a ser estudada melhor pela doutrina o retorno do ausente e suas consequências, conforme o aparecimento de casos nos Tribunais, e que, nesse sentido, o direito comparado será de grande valia. Em contrapartida, para Maria Berenice Dias $^{21}$, no silêncio da lei, e determinando ela que a morte presumida dissolve o vínculo do casamento, o novo casamento do cônjuge do ausente é válido no caso do seu retorno, sob o argumento de que não há nulidade sem expressa previsão legal.

Sobre a ausência, cumpre destacar que, para Sílvio Rodrigues: ${ }^{22}$

Após a promulgação da Constituição Federal de 1988, cujo art. 226, § $6^{\circ}$, possibilitou o divórcio direto após a separação de dois anos, a solução no Brasil é simples. Dois anos após o desaparecimento do ausente, pode o seu cônjuge, provando tal fato, requerer e obter o divórcio. Assim, poderá, se o quiser, recasar-se.

Apesar de o autor tratar a ausência dessa maneira, é preciso cautela,

19 RODRIGUES, Sílvio. Direito civil: direito de família: volume 6.28 ed. rev. e atual. por Francisco José Cahali, de acordo com o novo Código Civil (Lei n. 10.406, de 10/01/2002). São Paulo: Saraiva, 2008, p. 432.

20 VENOSA, Sílvio de Salvo. Direito civil: direito de família. 11. ed. v. 6. São Paulo: Atlas, 2011, p. 487.

21 DIAS, Maria Berenice. Manual de direito das famílias. 7. ed. rev., atual. e ampl. São Paulo: Editora Revista dos Tribunais, 2010, p. 296-297.

22 RODRIGUES, Sílvio. Direito civil: direito de família: volume 6.28 ed. rev. e atual. por Francisco José Cahali, de acordo com o novo Código Civil (Lei n. 10.406, de 10/01/2002). São Paulo: Saraiva, 2008, p. 432. 
pois há aqueles que entendem que só após 20 (vinte) anos é que se poderia dissolver o casamento pela morte presumida determinada pela ausência.

\subsection{Pelo divórcio}

Além do fim do casamento pela morte, o divórcio também tem o papel de finalizar esse vínculo. Ao falar em divórcio, há alguns pontos de vista que precisam ser abordados, dentre eles: a ótica passada do desquite, o advento da separação com o divórcio conversivo e, por fim, o novo divórcio direto.

\subsubsection{O desquite}

$\mathrm{O}$ desquite ${ }^{23}$ veio como o primeiro instituto a ser aceito no direito brasileiro no sentido de possibilitar a dissolução da sociedade conjugal, inserido no texto original do Código
Civil de 1916, no inciso III do artigo 315 , que dispunha:

Art.315. A sociedade conjugal termina: I. Pela morte de um dos cônjuges.

II. Pela nulidade ou anulação do casamento.

III. Pelo desquite, amigável ou judicial.

Parágrafo único. O casamento válido só se dissolve pela morte de um dos cônjuges, não se lhe aplicando a presunção estabelecida neste Código, art. 10, segunda parte.

Curioso é que, antes de existir o desquite, o Decreto n. 181, de 24 de janeiro de 1890, falava em divórcio ${ }^{24}$ como forma de dissolução da sociedade conjugal quando casamento era válido. Pontes de Miranda diz que tal vocábulo era usado pela linguagem vulgar e pela terminologia jurídica em dois sentidos: o romano, que de-

23 Desquite foi um termo criado no Brasil, em substituição ao divórcio do Decreto n. 181/1890, que não tinha a mesma significação do atual divórcio. Inácio de Carvalho Neto diz a respeito que: "Mantinha-se, portanto, a indissolubilidade do vínculo conjugal do regime anterior. Alterou-se, entretanto, a nomenclatura: o que, no Decreto 181/1890, era chamado de divórcio passou a se chamar desquite, palavra esta de criação nacional, que ficou consagrada pela doutrina e pelo povo brasileiro. A alteração da nomenclatura foi salutar, já que a palavra divórcio (que se referia ao divórcio não vincular), no sistema anterior, era fonte de confusões, tendo em vista que, em outros países, a mesma era usada, como até hoje, como forma de dissolução do vínculo conjugal, portanto, como divórcio vincular” (2009, p. 85).

24 Informação disponível em: <http://www6.senado.gov.br/legislacao/ListaNormas. action?numero=181\&tipo_norma=DEC\&data=18900124\&link=s $>$. Acesso em: 20 out. 2011. 
signava a dissolução do vínculo, e o canônico, como simples separação de corpos. $^{25}$

O desquite dissolvia a sociedade conjugal, mas não o vínculo, tal como na separação judicial, que veio a substituí-lo através da Lei n. 6.515/1977, a chamada Lei do Divórcio. O não desfazimento do vínculo resultava na impossibilidade de novo casamento. ${ }^{26}$

Para que o desquite ocorresse, o Código Civil de 1916 previa que, ou ele deveria ser consensual para os casados há mais de 2 (dois) anos (artigo 318), ou houvesse fundado motivo, que poderia ser: adultério (sob as condições do artigo 319$)^{27}$, tentativa de morte, sevícia ou injúria grave, ou, ainda, pelo abandono do lar durante 2 (dois) anos consecutivos (artigo 317), rol esse taxativo.

No antigo código, os artigos 315 a 324 regiam a dissolução da sociedade conjugal, que com o desquite findava o regime de bens e o dever de coabitação, mas mantinha o vínculo do casamento que podia ser restaurado a qualquer momento (artigo 323 do Código Civil de 1916).

Tem-se por oportuno lembrar que foi com a Constituição de $1934^{28}$ que a família passou a ser amparada constitucionalmente, dedicando-se a ela um capítulo, com quatro artigos, cujo artigo 144, o seu primeiro, dizia que:

A família, constituída pelo casamento indissolúvel, está sob a proteção especial do Estado. Parágrafo único - A lei civil determinará os casos de desquite e de anulação de casamento, havendo sempre recurso ex officio, com efeito suspensivo. (grifou-se).

Nesse sentido, a indissolubilidade do vínculo permanecia como um reflexo da influência católica no contexto social. Lutava-se pela manutenção das uniões sob ideia católica das relações matrimoniais eternas.

As Constituições de 1937, 1946 e 1967 persistiram na ideia de casamento como união indissolúvel, foi somente

25 PONTES DE MIRANDA. Tratado de direito de família. V. 1. Atualizado por Vilson Rodrigues Alves. Campinas: Bookseller, 2001, p. 441.

26 VENOSA, Sílvio de Salvo. Direito civil: direito de família. 11. ed. v. 6. São Paulo: Atlas, 2011, p. 161.

27 Código Civil de 1916. “Art. 319. O adultério deixará de ser motivo para o desquite: I - Se o autor houver concorrido para que o réu o cometa. II - Se o cônjuge inocente lhe houver perdoado. Parágrafo único. Presume-se perdoado o adultério, quando o cônjuge inocente, conhecendo-o, coabitar com o culpado”.

28 BRASIL. Constituições Anteriores de 1824 a 1967 EMC n. 1 de 1969. Diário Oficial da União, Poder Executivo, Brasília, DF. Disponível em: <http://www4.planalto. gov.br/legislacao/legislacao-historica/constituicoes-anteriores-1\#content $>$. Acesso em: 23 abr. 2011. 
com a Constituição de 1969 e o advento da Emenda Constitucional n. 9 de 1977 que o caráter da indissolubilidade foi retirado e inserida a nova redação ao parágrafo $1^{\circ}$ do artigo 175 , que dispunha: "O casamento somente poderá ser dissolvido nos casos expressos em lei, desde que haja prévia separação judicial por mais de três anos”.

O fato é que a evolução das Constituições, apesar de lenta, seguia os anseios e as preocupações de suas épocas. A própria mudança de nomenclatura do desquite para a separação estabelecia um tipo de transição importante. Apesar disso, a existência de um instituto como o desquite, que era a separação, ainda indicava a resistência nessa mudança, de abrir-se à dissolução do vínculo matrimonial, por um anseio em manter a estrutura familiar. Insistia-se na tentativa de evitar o divórcio através do requisito da separação prévia, fosse de corpos ou judicial.

A abertura ao divórcio teve na resistência da Igreja um forte obstáculo. Mesmo com a aprovação da Lei do Divórcio ainda haviam resquícios desse sistema fechado. Segundo Maria Berenice Dias:

Para a aprovação da Lei do Divórcio (6.515/77), foi necessário manter o desquite, tendo ocorrido somente uma singela alteração terminológica. O que o Código Civil chamava de desquite (ou seja, não "quites", alguém em débito para com a sociedade) a Lei do Divórcio denominou de separação, com idênticas características: põe fim à sociedade conjugal, mas não dissolve o vínculo matrimonial. ${ }^{29}$

Apesar do longo tempo entre discussões de divorcistas e antidivorcistas, que acabaram postergando a adoção do divórcio no Direito brasileiro, entra em vigor a Lei n. 6.515, de 26 de dezembro de 1977, revogando, portanto, o desquite. Após a Lei do Divórcio, o Código Civil de 2002 segue mantendo as evoluções no sentido da dissolução da sociedade e do vínculo conjugal, a princípio através do divórcio conversivo, que será falado a seguir.

\subsubsection{A separação e o divórcio}

No contexto mencionado, foi por meio da Emenda Constitucional $n^{\circ} 9$ de 1977 que abriu-se a possibilidade de dissolução do casamento. Com a Lei n. 6.515 de 26 de dezembro de 1977 surgia o divórcio ${ }^{30}$ no Brasil. $\mathrm{O}$ artigo $2^{\circ}$ da Lei do Divórcio estabelecia:

\section{Art $2^{\circ}$ - A Sociedade Conjugal termina:}

29 DIAS, Maria Berenice. Manual de direito das famílias. 7. ed. rev., atual. e ampl.. São Paulo: Editora Revista dos Tribunais, 2010, p. 288.

30 É curioso destacar trecho do livro de Inácio de Carvalho Neto que fala do divórcio como tendo um significado diferente à época do Decreto n. 181, de 24 de janeiro de 
I - pela morte de um dos cônjuges;

II - pela nulidade ou anulação do casamento;

III - pela separação judicial;

IV - pelo divórcio.

Parágrafo único - O casamento váli-

do somente se dissolve pela morte de um dos cônjuges ou pelo divórcio. (grifou-se.)

Separação e divórcio vieram no sentido de substituir o antigo desquite. Possibilitando o término do vínculo conjugal, que não pela morte, e ao mesmo tempo mantendo o desquite, renomeado como separação - meio pelo qual se põe termo aos deveres de coabitação, fidelidade recíproca e ao regime de bens do casamento (art. $3^{\circ}$ da Lei n. 6.515/1977). Os requisitos para a ocorrência da separação eram: que o casamento tivesse mais de dois anos (art. $4^{\circ}$, da lei supra) e que se cumprisse as condições do art. $5^{\circ}$ :

Art $5^{\circ}$ A separação judicial pode ser pedida por um só dos cônjuges quando imputar ao outro conduta desonrosa ou qualquer ato que importe em grave violação dos deveres do casamento e tornem insuportável a vida em comum.

$\S 1^{\circ}$ A separação judicial pode, também, ser pedida se um dos cônjuges provar a ruptura da vida em comum há mais de um ano consecutivo, e a impossibilidade de sua reconstituição. ${ }^{31}$

$\S 2^{\circ}$ - O cônjuge pode ainda pedir a separação judicial quando o outro estiver acometido de grave doença mental, manifestada após o casamento, que torne impossível a continuação da vida em comum, desde que, após uma duração de 5 (cinco) anos, a enfermidade tenha sido reconhecida de cura improvável. $\S 3^{\circ}$ - Nos casos dos parágrafos anteriores, reverterão, ao cônjuge que não houver pedido a separação judicial, os remanescentes dos bens que levou para o casamento, e, se o regime de bens adotado o permitir, também a meação nos adquiridos na constância da sociedade conjugal.

Conforme Yussef Said Cahali ${ }^{32}$, com a Lei do Divórcio vieram profundas transformações: “[...] mantendo o

1890, a Lei do Matrimônio: “Nos arts. 80 a 92 cuidou o Decreto do que chamou de divórcio, que, no entanto, não se identifica com o que hoje conhecemos por divórcio, já que dispôs, em seu art. 88, que 'o divórcio não dissolve o vínculo conjugal...' . O art. 93 do referido Decreto afirmava que o casamento válido só se dissolveria com a morte de um dos cônjuges. Tratou, o Decreto, da anulação do casamento nos arts. 61 a 79” (2009, p. 83).

31 Redação dada pela Lei n. 8.408, de 13 de fevereiro de 1992. O texto anterior desse parágrafo previa que a ruptura deveria ser de mais de 5 (cinco) anos.

32 CAHALI, Yussef Said. Divórcio e separação. 11. ed. rev. ampl. e atual. de acordo com o Código Civil de 2002. São Paulo: Editora Revista dos Tribunais, 2005, p. 301. 
desquite sem causa culposa, na forma de separação judicial consensual, e a separação litigiosa por infração dos deveres conjugais, introduziu a separação litigiosa sem causa culposa dos $\S \S 1^{\circ}$ e $2^{\circ}$ do seu art. $5^{\circ}[\ldots]^{\prime}$.

É importante destacar que, apesar de ainda existir menção no Código Civil (artigo 1.572 sob as hipóteses do artigo 1.573), a culpa foi, de certa forma, deixada de lado pelos tribunais, uma vez que ao fim terminavam por prejudicar ambos os cônjuges, que já se viam enfrentando a difícil situação da separação, é o que Venosa ${ }^{33}$ afirma no trecho abaixo:

Era de toda conveniência que esse texto legal fosse reformulado. Há que se entender agora como extirpado, embora possam ocorrer dúvidas nos tribunais em virtude da singeleza do texto constitucional. A infindável discussão por vezes instalada no processo acerca da insuportabilidade da vida em comum é inócua e inconveniente, para os cônjuges e para a prole.

A culpa é, sem dúvida, uma questão que demanda longas discussões, ainda que se entenda que a vontade de separar seria bastante para efetivar o pedido, que só se alonga em traumas através das discussões de quem foi o culpado, deixar-se-á a culpa para analisar em outra oportunidade, seguindo-se ao tema “separação”.

\subsubsection{Separação}

Separação ${ }^{34}$ é o "ato ou efeito de separar ou separarem-se pessoas ou coisas moralmente ou fisicamente unidas; desunião, divisão, partição”, o "ato ou fato de deixar as pessoas amigas ou os parentes; afastamento”, a "ruptura de união conjugal”. Pela mesma fonte, a separação de corpos seria a medida preliminar das ações de nulidade ou anulação de casamento e da de desquite, em virtude da qual um dos cônjuges deixa o domicílio conjugal. Nesse sentido de separação de pessoas e bens seria a "suspensão da sociedade conjugal decretada judicialmente a requerimento de um dos cônjuges, durante a qual ficam separados do outro corporalmente e administrando cada um o que lhe pertence ou lhe foi atribuído em partilha”.

33 VENOSA, Sílvio de Salvo. Direito civil: direito de família. 11. ed. v. 6. São Paulo: Atlas, 2011, p. 195.

34 SEPARAÇÃO. In: MICHAELIS Moderno Dicionário da Língua Portuguesa. São Paulo: Melhoramentos, 1998. Disponível em: <http://michaelis.uol.com.br/moderno/ portugues/index.php?lingua=portugues-portugues\&palavra=separa\%E7\%E3o>. Acesso em: 05 dez. 2011. 
Os significados apresentados au-xiliam na compreensão de que a separação, atualmente, pode ser dividida em 4 (quatro) modalidades, separação de fato, de corpos e judicial, não deixando de mencionar a recente possibilidade de separação por via administrativa, também chamada de extrajudicial.

\section{a) Separação de fato}

A primeira modalidade de separação identificada é a de fato, não há dificuldades em entendê-la, pois refere-se ao fato em si de duas pessoas que conviviam romperem o relacionamento, mais precisamente a coabitação, não culminando necessariamente numa separação judicial. Numa definição bem simples:

A separação de fato pode ser entendida como um fenômeno natural em que os cônjuges decidem por fim ao vínculo conjugal, sem, no entanto, recorrer aos meios legais. Funcionando, por vezes, como válvula de escape para os casais que não querem, não podem ou não se sentem preparados o bastante para se valer da separação judicial ou do divórcio. ${ }^{35}$
Com a separação de fato, basicamente, ocorre o fim da coabitação. Ela é confundida com a separação de corpos, mas há, sim, uma significativa diferença.

\section{b) Separação de corpos}

A separação de corpos, de outro modo, é um tipo de medida cautelar utilizado para quando há alguma questão que demande o afastamento do cônjuge do lar, ainda que já separados de fato, como, por exemplo, em decorrência de violência. As medidas cautelares, como se sabe, são requeridas face a algum tipo de urgência. ${ }^{36}$

\section{c) Separação judicial e extrajudicial}

A separação judicial é aquela do artigo 1.571, inciso III, do Código Civil, a que a Constituição de 1988, antes da Emenda Constitucional n. 66/2010, tinha por requisito à concessão do divórcio.

A separação, através da Lei $n$. 6.515/1977, veio, de certo modo, "[...] mantendo o desquite sem causa culposa, na forma de separação judicial consensual, e a separação litigio-

35 CHAVES, Luís Cláudio da Silva. A separação de fato e seus efeitos. Domtotal.com, Belo Horizonte, 26 ago. 2009. Disponível em: <http://www.domtotal.com/colunas/detalhes.php?artId=903 >. Acesso em: 08 dez. 2011.

36 VENOSA, Sílvio de Salvo. Direito Civil: direito de família. 11. ed. v. 6. São Paulo: Atlas, 2011, p. 204-205. 
sa por infração dos deveres conjugais, introduziu a separação litigiosa sem causa culposa dos $\S \S 1^{\circ}$ e $2^{\circ}$ do seu art. $\left.5^{\circ}[\ldots]\right]^{37}$

Assim, em substituição ao desquite, veio a separação judicial, que pode ser dividida em consensual (quando há acordo entre os cônjuges) ou litigiosa (quando não há acordo).

\section{c.1) Separação consensual (artigo 1.574 do Código Civil e artigos 1.120 a 1.124 do Código de Processo Civil)}

A separação consensual ocorre mediante mútuo consentimento, esse, portanto, é um dos seus pré-requisitos. Também, por esse motivo, todas as questões concernentes à separação de pronto já ficam estabelecidas pelo próprio casal (como, por exemplo, a guarda dos filhos, se houverem, direito de visita, pagamento de alimentos, inclusive a partilha dos bens, que lhe é livre e válida quando não há vício de vontade). ${ }^{38} \mathrm{O}$ outro pré-requisito é que o casamento tenha pelo menos 1 (um) ano.

Conforme Fabiana e Theobaldo Spengler $^{39}$, tal prazo refere-se a uma imposição do legislador com a finalidade de evitar que de forma "precipitada e leviana” o casal busque a dissolução do matrimônio logo na primeira briga após o casamento.

Antes do Código Civil de 2002, no artigo $4^{\circ}$ da Lei n. 6.515, a Lei do Divórcio, para tal separação era necessário que o casamento tivesse pelo menos 2 (dois) anos. ${ }^{40}$

A separação consensual, quando não houver filhos menores ou incapazes, pode ocorrer extrajudicialmente, com a assistência de advogado. Essa possibilidade foi inserida no ordenamento jurídico através da Lei n. 11.441/2007. Os requisitos são os mesmos da separação consensual judicial, e ela é realizada através de escritura pública no Tabelionato de Notas (artigo 1.124-A do Código de Processo Civil). ${ }^{41}$

37 CAHALI, Yussef Said. Divórcio e separação. 11. ed. rev. ampl. e atual. de acordo com o Código Civil de 2002. São Paulo: Editora Revista dos Tribunais, 2005, p. 301.

38 DINIZ, Maria Helena. Curso de direito civil brasileiro: direito de família. 25. ed. v. 5. São Paulo: Saraiva, 2010, p. 288.

39 SPENGLER, Fabiana Marion; SPENGLER NETO, Theobaldo. Inovações em direito e processo de família. Porto Alegre: Livraria do Advogado, 2004, p. 145.

40 PONTES DE MIRANDA, Tratado de direito de família. V. 1. Atualizado por Vilson Rodrigues Alves. Campinas: Bookseller, 2001, p. 449.

41 DINIZ, Maria Helena. Curso de direito civil brasileiro: direito de família. 25. ed. v. 5. São Paulo: Saraiva, 2010, p. 329-331. 
Questão importante a ser destacada nesse sentido é sobre a possibilidade ou não da separação consensual extrajudicial ser realizada por procuração. Para Maria Helena Diniz, isso não seria possível em face de ser ato personalíssimo, diferente do casamento. Trata-se da desconstituição de direitos, que necessita da presença do cônjuge para que não haja dúvida sobre o seu desejo. Em contrapartida, a autora esclarece que, apesar de sua opinião, há quem entenda o contrário, como Zeno Veloso e Christiano Chaves de Farias, inclusive sendo o que determina o art. 36 da Resolução n. 35/2007 do CNJ (Conselho Nacional de Justiça), e sob a analogia do art. 1.535 do CC, que trata do casamento. ${ }^{42}$

\section{c.2) Separação litigiosa (artigos}

\subsection{2 e 1.573 do Código Civil)}

De outro modo, a separação litigiosa ocorre quando apenas um dos cônjuges requer a separação, uma vez que não há consenso sobre a mesma, desimportando o tempo de casamento, nas hipóteses de grave violação dos deveres do casamento e de insuportabilidade da vida em comum, conforme o artigo 1.572 do Código Civil. Ou seja, aqui ainda se vê um resquício da culpa pela separação.
De acordo com o artigo 1.573 do Código Civil, a impossibilidade da vida em comum pode ser determinada por: adultério, tentativa de morte, sevícia ou injúria grave, abandono voluntário do lar durante um ano contínuo, condenação por crime infamante, conduta desonrosa, ou outros fatos que a critério do juiz colaborem para a insuportabilidade da convivência.

Nessa seara, a doutrina (dentre elas Maria Helena Diniz e Fabiana e Theobaldo Spengles) estabelece três tipos de separação litigiosa, quais sejam: remédio, falência e sanção.

\section{c.2.1) Separação remédio (artigo 1.572, parágrafo $2^{\circ}$, do Código Civil)}

A separação remédio é aquela em que o seu pedido baseia-se no acometimento de doença mental grave de um dos cônjuges, advindo na constância do casamento e, após dois anos, reconhecida de cura improvável. Tal dispositivo já existia na Lei n. 6.515/1977, em seu artigo 5º parágrafo segundo, porém o prazo era de 5 (cinco) anos.

A doutrina teria dado esse tipo de separação por superada, ante a possibilidade do artigo 40 da Lei do Divórcio que permitia o divórcio direto

42 DINIZ, Maria Helena. Curso de direito civil brasileiro: direito de família. 25. ed. v. 5. São Paulo: Saraiva, 2010, p. 333-334. 
depois de 2 (dois) anos (consecutivos e comprovados) de separação de fato. ${ }^{43}$ De fato, avaliando a situação, seria muito mais vantajoso requerer o divórcio direto, ante a desnecessidade de motivação que não fosse apenas os 2 (dois) anos de separação de fato.

Tal dispositivo vai de encontro com o dever de mútua assistência, em contrapartida que acabava sendo uma punição ao que saía do casamento porque perdia o direito à meação dos bens do doente, se o regime do casamento era de comunhão universal (artigo 1.572, parágrafo terceiro, do Código Civil). ${ }^{44}$

\section{c.2.2) Separação falência (artigo \\ 1.572, parágrafo primeiro do CC)}

A separação falência ocorre quando o casal encontra-se separado por mais de 1 (um) ano e não há possibilidade de reconciliação.

Seria, portanto, uma separação com causa objetiva, embora fundada por um motivo somente que diga respeito à separação fática ${ }^{45}$, e não adentra na intimidade do casal.

\section{c.2.3) Separação sanção (caput do artigo 1.572 e artigo 1.573 do Código Civil)}

Na separação sanção encontra-se a discussão da culpa, nela um cônjuge imputa ao outro conduta desonrosa ou prática de ato que determine a grave violação dos deveres do casamento, que torna, por sua vez, a vida em comum insuportável. Foi mais uma manutenção do Código Civil de 2002 do texto da Lei n. 6.515/1977, artigo $5^{\circ} .{ }^{46}$

Dos motivos do artigo 1.573 é possível dizer que: há dificuldade na determinação do que seja conduta desonrosa, porque sua análise é bastante subjetiva; o adultério seria infração ao dever de fidelidade; e no que tange ao abandono voluntário do lar durante um ano contínuo, recairia na mes-

43 SPENGLER, Fabiana Marion; SPENGLER NETO, Theobaldo. Inovações em direito e processo de família. Porto Alegre: Livraria do Advogado, 2004, p. 147.

44 DIAS, Maria Berenice. Manual de direito das famílias. 7. ed. rev., atual. e ampl. São Paulo: Editora Revista dos Tribunais, 2010, p. 307.

45 SANTOS, Luiz Felipe Brasil dos. A separação judicial e o divórcio no novo Código Civil brasileiro. Revista Brasileira de Direito de Família. Porto Alegre: Síntese, IBDFAM. v. 1, n. 1, abr.jun. 1999, p. 152. apud SPENGLER, Fabiana Marion; SPENGLER NETO, Theobaldo. Inovações em direito e processo de família. Porto Alegre: Livraria do Advogado, 2004, p. 150.

46 SPENGLER, Fabiana Marion; SPENGLER NETO, Theobaldo. Inovações em direito e processo de família. Porto Alegre: Livraria do Advogado, 2004, p. 151. 
ma questão da separação remédio, ou seja, melhor seria fundamentar o pedido no artigo 1.571, parágrafo segundo, que tem os mesmos requisitos, mas não tem discussão da culpa. ${ }^{47}$

\section{d) Questões importantes a respeito da separação}

Alguns pontos não podem deixar de ser considerados ao se discorrer sobre a separação: a culpa, os alimentos e o nome de casado são alguns deles que serão tratados a seguir:

\section{d.1) A culpa na separação}

A culpa é bastante discutível. Apesar de manter-se no Código Civil de 2002 como embasadora da separação litigiosa, sua função seria apenas determinação de um culpado, o que só fundamenta a questão dos alimentos e da manutenção ou não do nome de casado.

Para a doutrina ${ }^{48}$ estudada, é praticamente unânime que basta o desamor para o fim de uma relação, qualquer outro fundamento apenas acirraria a discussão e promoveria o desgaste dos envolvidos. Devendose preservar a intimidade face ao retrocesso estabelecido pela lei. ${ }^{49}$

De outro modo, a culpa é um resquício da influência da Igreja para manutenção do casamento com vistas à moral e à ordem pública. ${ }^{50}$

É interessante citar o que diz Fabiana e Theobaldo Spengler ${ }^{51}$ sobre a experiência da Alemanha, em que

[...] aboliram, há muito, qualquer possibilidade processual de se pesquisar a culpa na separação, por entenderem que a máquina processual judiciária pode ser melhor aproveitada se concentrar seus esforços em equipes multidisciplinares para ensinar aqueles que se separam como deverão retomar suas experiências afetivas, corrigindo seus erros para que seus próximos relacionamentos sejam exitosos.

A iniciativa alemã seria uma solução bem interessante, observado o fato de que a discussão da culpa apenas acirra as disputas decorrentes

47 SPENGLER, Fabiana Marion; SPENGLER NETO, Theobaldo. Inovações em direito e processo de família. Porto Alegre: Livraria do Advogado, 2004, p. 151 - 152.

48 Fabiana e Theobaldo Spengles, Maria Berenice Dias e Sílvio de Salvo Venosa, por exemplo.

49 VENOSA, Sílvio de Salvo. Direito civil: direito de família. 11. ed. v. 6. São Paulo: Atlas, 2011, p. 160.

50 SPENGLER, Fabiana Marion; SPENGLER NETO, Theobaldo. Inovações em direito e processo de família. Porto Alegre: Livraria do Advogado, 2004, p. 157.

51 SPENGLER, Fabiana Marion; SPENGLER NETO, Theobaldo. Inovações em direito e processo de família. Porto Alegre: Livraria do Advogado, 2004, p. 154-155. 
da separação e provoca ainda mais a exaltação dos ânimos dos cônjuges em processo de separação. Além disso, se fala, ainda, na inconstitucionalidade dessa discussão, por ir de encontro com o princípio da dignidade da pessoa humana e a inviolabilidade da intimidade, o que se explica pela grande exposição e pelo constrangimento a que as pessoas nesse estado se submetem. ${ }^{52}$

Os efeitos da culpa ao fim e ao cabo se restringiriam à determinação do pagamento das custas judiciais, e à perda do nome do outro cônjuge (quando não causar prejuízo, seja pela distinção com o nome dos filhos ou pelo fato de o indivíduo já ser pessoa conhecida pelo nome de casado há muitos anos). ${ }^{53}$

Além disso, não se pode deixar de mencionar a repercussão dessa questão da culpa nos alimentos. Antes um dos benefícios da determinação da culpa era o direito aos alimentos, que atualmente pode ser conferido sem a determinação da culpa, deixando, portanto, de ter cunho indenizatório. A novidade é que dentro do binômio necessidade-possibilidade o próprio culpado pode receber alimentos do outro cônjuge. ${ }^{54}$ Essas disposições sobre alimentos encontram-se no Código Civil, artigo 1.704 .

\section{d.2) Efeitos quanto ao nome}

A atual faculdade de acrescer o nome veio com a Lei do Divórcio e manteve-se no atual Código Civil. Antes tratava-se de uma imposição. ${ }^{55}$

De acordo com Venosa ${ }^{56}$, na Lei do Divórcio, a mulher vencida no processo de separação perdia o direito ao uso do nome (artigo 17), o mesmo para quando ela tinha a iniciativa de se separar porque havia ruptura da vida em comum por mais de 1 (um) ano ou porque o marido havia sido acometido de doença mental grave após o casamento (artigo $5^{\circ}$, parágrafos $1^{\circ}$ e $2^{\circ}$ ). Se vencedora na ação, lhe era facultado permanecer ou renun-

52 SPENGLER, Fabiana Marion; SPENGLER NETO, Theobaldo. Inovações em direito e processo de família. Porto Alegre: Livraria do Advogado, 2004, p. 157.

53 SPENGLER, Fabiana Marion; SPENGLER NETO, Theobaldo. Inovações em direito e processo de família. Porto Alegre: Livraria do Advogado, 2004, p. 158.

54 SPENGLER, Fabiana Marion; SPENGLER NETO, Theobaldo. Inovações em direito e processo de família. Porto Alegre: Livraria do Advogado, 2004, p. 158-160.

55 VENOSA, Sílvio de Salvo. Direito civil: direito de família. 11. ed. v. 6. São Paulo: Atlas, 2011, p. 165.

56 VENOSA, Sílvio de Salvo. Direito civil: direito de família. 11. ed. v. 6. São Paulo: Atlas, 2011, p. 165-166. 
ciar ao nome a qualquer tempo (artigo 18). Além disso, havia a opção de não ser alterado o nome em face de prejuízo, seja porque diferenciar-se-ia o nome de família com o dos filhos ou dano grave reconhecido pela decisão (artigo 25). Questões que se mantiveram no Código Civil de 2002, em seu artigo 1.578 .

Segue jurisprudência recente a respeito:

APELAÇÃO CÍVEL. AÇÃO DE SEPARAÇÃO JUDICIAL. REVELIA. PARTILHA. IMÓVEIS. DÍVI-

DAS. Mesmo se tratando de direitos disponíveis - patrimoniais -, não há como, pela revelia do réu, determinar-se a partilha dos imóveis ou das alegadas dívidas nesta ação, se a autora não demonstra o direito à partilha, através de documentos hábeis a respeito do patrimônio imobiliário e das dívidas. Partilhamento que deve ser realizado em ação própria ou em sede de ação de divórcio. NOME DE CASADA. RETORNO AO NOME DE SOLTEIRA. OPÇÃO. A permanência do nome de casada é uma opção da separanda, conforme 0 art. 1.578, § $2 .^{\circ}$, do CC/02 ["Nos demais casos caberá a opção pela conservação do nome de casado"]. Havendo manifestação expressa no apelo em retornar ao nome de solteira, impõe-se acolher a pretensão, com a reforma da sentença que determinou a permanência do nome de casada à separanda. HONORÁRIOS ADVOCATÍCIOS. Atento aos ditames do art. 20, $\S 4 .^{\circ}$, do CPC, cabe majorar a verba honorária em favor da advogada da autora, em quantia condizente com o trabalho apresentado, o qual deve ser remunerado dignamente. APELAÇÃO PARCIALMENTE PROVIDA. (SEGREDO DE JUSTIÇA) (Apelação Cível No 70032247611, Sétima Câmara Cível, Tribunal de Justiça do RS, Relator: André Luiz Planella Villarinho, Julgado em 09/06/2010). (grifou-se)

SEPARAÇÃO JUDICIAL. GENITORA QUE RETORNA AO USO DO NOME DE SOLTEIRA. ALTERAÇÃO NO ASSENTO DE NASCIMENTO DA PROLE. DESNECESSIDADE DE AJUIZAMENTO DE AÇÃO PRÓPRIA. Retornando a mulher ao uso do nome de solteira, atendo ao princípio da economia processual que a alteração do patronímico da genitora no assento de nascimento do filho menor de idade ocorra nos próprios autos da separação, sendo desnecessária a propositura de ação própria para tanto. Agravo provido. (Agravo de Instrumento $\mathrm{N}^{\circ} 70021907175$, Sétima Câmara Cível, Tribunal de Justiça do RS, Relator: Maria Berenice Dias, Julgado em 19/12/2007).

**AÇÕES DE DIVÓRCIO E DE ALIMENTOS. ALIMENTOS DEVIDOS À EX-CÔNJUGE. DEVER DE ASSISTÊNCIA MÚTUA. MAJORAÇÃO DA VERBA ALIMENTAR. BINÔMIO POSSIBILIDADE/ NECESSIDADE. NECESSIDADE COMPROVADA. O dever de prestar alimentos é devido porque calcado na assistência mútua existente entre os cônjuges, mas sobretudo quando patente o binômio necessidade/pos- 
sibilidade. IPERGS. Sendo o varão beneficiário do plano de saúde do IPERGS, demonstrada a dependência econômica da ex-esposa, deve ela ser mantida como sua dependente. USO DO NOME DE CASADA. Inexiste qualquer prejuízo, ao varão, no sentido da ex-esposa continuar usando o nome de casada, a qual é identificada há quarenta e nove anos, já que o art. 1.578, § $2^{\circ}$, do CC, prevê a opção de conservação do nome de casada. INCIDÊNCIA SOBRE O $13^{\circ}$ SALÁRIO. A obrigação alimentar incide sobre o $13^{\circ}$ salário do alimentante. Precedentes jurisprudenciais. Primeira apelação cível desprovida e $2^{\mathrm{a}}$ apelação provida, de plano. (Apelação Cível No 70037969466, Sétima Câmara Cível, Tribunal de Justiça do RS, Relator: Jorge Luís Dall’Agnol, Julgado em 30/06/2011).

Sendo assim, a questão do nome de casado dependerá, fundamentalmente, do prejuízo de sua retirada. Avaliação feita pelo juiz da causa conforme a justificativa dada para sua permanência.

\subsubsection{Divórcio}

Pois bem, enquanto a separação dissolvia apenas a sociedade conjugal, o divórcio dissolvia por completo o casamento. Dizia o art. 24 da Lei n. 6.515/1977 que: "O divórcio põe termo ao casamento e aos efeitos civis do matrimônio religioso". Em outras palavras, o divórcio inserido pela Lei n. 6.515/1977 era conversivo, para que ele fosse determinado era preciso prévia separação, de fato por mais de 2 (dois) anos e judicial por mais de 1 (um) ano, quando então era convertida em divórcio (art. 226, § $6^{\circ}$, da Constituição Federal de 1988, e art. 1.580 do Código Civil de 2002).

Ao longo dos anos, após a instituição do divórcio conversivo, a abertura legislativa aos divorcista foi sendo percebida através das alterações dos prazos. Originalmente, a previsão era de 3 (três) anos de separação judicial para a conversão em divórcio, e, posteriormente, com a Lei n. 8.408/1992, esse prazo passou a ser de 1 (ano) no mínimo. ${ }^{57}$ Para o pedido direto de Divórcio, em contrapartida, era necessário comprovar-se separação de fato por mais de 5 (cinco) anos, conforme a redação original do art. 40 da Lei do Divórcio, que modificado pela Lei $n$. 7.841/1989, passou a ser de 2 (dois) anos, como determinado pela Constituição de $1988 .^{58}$

57 RODRIGUES, Sílvio. Direito civil: direito de família. V. 6. 27. ed. atual. Por Francisco José Cahali, com anotações ao novo Código Civil (Lei nº 10. 406, de 10-1-2002). São Paulo: Saraiva, 2002, p. 262-263.

58 VENOSA, Sílvio de Salvo. Direito civil: direito de família. 11. ed. v. 6. São Paulo: Atlas, 2011, p. 163. 
Além disso, é importante lembrar que o art. 26 da Lei n. 6.515 previa que o cônjuge que houvesse pedido a separação permanecia com o dever de assistência com relação ao outro, ainda que houvesse a possibilidade de novo casamento, o que configurava um resquício antidivorcista.

De certo modo, o grande divisor de águas no Direito de Família foi a Constituição Federal de 1988, que trouxe significativas mudanças, inclusive no que diz respeito à dissolução da sociedade conjugal, conforme já dito anteriormente. Deu-se abertura ao divórcio, alargado ao longo do tempo, como uma resposta aos anseios sociais. Carvalho Neto $^{59}$ diz que:

O avanço, a nosso ver, foi extremado, facilitando, por demais, a obtenção do divórcio. Deu-se, assim, o que temiam os antidivorcistas de 1977: aprovando-se o divórcio, em princípio com limites, em pouco tempo seria ele extremamente alargado.
A vinda das disposições sobre separação e divórcio na Constituição de 1988 fez com que já no Código Civil de 2002, nos arts. 1.571 a 1.582, houvesse um título especialmente conferido à "Dissolução da Sociedade e do Vínculo Conjugal”, que, por sua vez, derrogou a Lei do Divórcio no que tange ao direito material da separação e do divórcio, mas não com relação às disposições processuais. ${ }^{60}$

Nesse sentido, o Código Civil de 2002 manteve algumas das disposições da Lei n. 6.515/1977, mas demonstrou que havia vindo para consolidar as mudanças já determinadas pela Constituição, dentre elas o caput e os incisos do art. $2^{\circ}$ que foram mantidos pelo art. 1.571 do Código Civil. ${ }^{61}$ Acrescentando-se a questão do ausente e da possibilidade de manutenção do nome de casado após o divórcio, exceto para quando determinado o contrário na sentença da separação judicial.

59 CARVALHO NETO, Inacio de. Separação e divórcio: teoria e prática. 10. ed. Curitiba: Juruá, 2009, p. 96.

60 VENOSA, Sílvio de Salvo. Direito civil: direito de família. 11. ed. v. 6. São Paulo: Atlas, 2011, p. 161.

61 “Art. 1.571. A sociedade conjugal termina: I - pela morte de um dos cônjuges; II - pela nulidade ou anulação do casamento; III - pela separação judicial; IV - pelo divórcio. $\S 1^{\circ} \mathrm{O}$ casamento válido só se dissolve pela morte de um dos cônjuges ou pelo divórcio, aplicando-se a presunção estabelecida neste Código quanto ao ausente. $\S 2^{\circ}$ Dissolvido o casamento pelo divórcio direto ou por conversão, o cônjuge poderá manter o nome de casado; salvo, no segundo caso, dispondo em contrário a sentença de separação judicial.” 
O fato é que no ano de 2010 foi aprovado projeto de emenda constitucional que efetuou a objetivação do § $6^{\circ}$ do art. 226 da Constituição Federal, excluindo o prazo para o requerimento do divórcio, resultado de mais um passo que o direito de família deu no sentido de atender às necessidades da sociedade.

\section{a) A Emenda Constitucional $n^{o}$} 66, de 13 de julho de 2010

Com o advento da Ementa Constitucional n. 66/2010, o $\S 6^{\circ}$ do art. 226 da Constituição ganhou nova redação, perdendo o pré-requisito "separação" para a concessão do divórcio. A modificação foi simples, mas as discussões posteriores demonstraram que não era bem assim na prática. Logo em seguida à emenda surgia a dúvida a respeito da manutenção ou não da separação.

A Emenda Constitucional n. 66/2010 surgiu como uma resposta à evolução do direito de família, através de um projeto sugerido pelo IBDFAM, o Instituto Brasileiro de Direito de Família, e apresentado na Câmara dos Deputados, em 15 de junho de 2005, pelo Deputado Antônio Carlos Biscaia.

O Projeto de Emenda Constitucional n. 413/2005 $5^{62}$, que restou na emenda em estudo, objetivava alterar o $\S 6^{\circ}$ do art. 226 da Constituição Federal, que dispunha sobre o divórcio, e que passaria a ter a seguinte redação: “O casamento civil pode ser dissolvido pelo divórcio consensual ou litigioso, na forma da lei”.

A justificativa do Deputado Antônio Carlos Biscaia para a proposição do referido projeto de ementa teria sido a de que:

[...] Não mais se justifica a sobrevivência da separação judicial, em que se converteu o antigo desquite. Criou-se, desde 1977, com o advento da legislação do divórcio, uma duplicidade artificial entre dissolução da sociedade conjugal e dissolução do casamento, como solução de compromisso entre divorcistas e antidivorcistas, o que não mais se sustenta. Impõe-se a unificação no divórcio de todas as hipóteses de separação dos cônjuges, sejam litigiosos ou consensuais. A submissão a dois processos judiciais (separação judicial e divórcio por conversão) resulta em acréscimos de despesas para o casal, além de prolongar sofrimentos evitáveis. Por outro lado, essa providência salutar, de acordo com valores da sociedade brasileira atual, evitará que a intimidade e a vida privada dos cônjuges e de suas famílias sejam revelados e trazidos ao espaço público dos tribunais, como todo o caudal de constrangimentos que provocam,

62 BRASIL. Projeto de Emenda Constitucional n. 413/2005. Diário Oficial da União, Poder Executivo, Brasília, DF, 15 jun. 2005. Disponível em: <http://www.camara.gov. br/sileg/integras/315665.pdf>. Acesso em: 23 mai. 2011. 
contribuindo para o agravamento de suas crises e dificultando o entendimento necessário para a melhor solução dos problemas decorrentes da separação.

Levantamentos feitos das separações judiciais demonstram que a grande maioria dos processos são iniciados ou concluídos amigavelmente, sendo insignificantes os que resultaram em julgamentos de causas culposas imputáveis ao cônjuge vencido. Por outro lado, a preferência dos casais é nitidamente para o divórcio que apenas prevê a causa objetiva da separação de fato, sem imiscuir-se nos dramas íntimos; Afinal, qual o interesse público relevante em se investigar a causa do desaparecimento do afeto ou do desamor?

O que importa é que a lei regule os efeitos jurídicos da separação, quando o casal não se entender amigavelmente, máxime em relação à guarda dos filhos, aos alimentos e ao patrimônio familiar. Para tal, não é necessário que haja dois processos judiciais, bastando o divórcio amigável ou judicial. ${ }^{63}$

$\mathrm{O}$ que se percebe ao ler os argumentos apresentados é que o objetivo da emenda seria basicamente possibilitar aos cidadãos o exercício de sua livre escolha, em manter-se casado ou não, evitar custos dispensáveis e constrangimentos e sofrimentos, que bem se sabe um litígio tem a tendência de maximizar.

Repise-se o fato de que conforme o próprio Deputado afirma, houve de 1977 (quando da Lei Divorcista) uma mudança de paradigma. Antes havia um interesse em manter-se apaziguada a questão da contraposição entre divorcistas e antidivorcistas, contudo, hoje, essa contraposição não é mais uma realidade. Sobre isso, Venosa ${ }^{64}$ afirma que:

A história do divórcio no Brasil traduz uma árdua e calorosa batalha legislativa e social, decorrente de uma longa e histórica tradição antidivorcista, sustentada basicamente pela Igreja, que erige o casamento com sacramento. As várias tentativas de admissão do divórcio no Brasil sempre esbarraram na oposição da Igreja Católica [...].

Para que o instituto do divórcio fosse admitido, várias concessões foram feitas aos antidivorcistas, como, por exemplo, a polêmica regra originária do art. 38 da Lei n. 6.515/77, segundo a qual o divórcio poderia ser formulado uma única vez, dispositivo revo-

63 BRASIL. Projeto de Emenda Constitucional n. 413/2005. Diário Oficial da União, Poder Executivo, Brasília, DF, 15 jun. 2005. Disponível em: <http://www.camara.gov. br/sileg/integras/315665.pdf>. Acesso em: 23 mai. 2011.

64 VENOSA, Sílvio de Salvo. Direito civil: direito de família. 11. ed. v. 6 São Paulo: Atlas, 2011, p. 205-206. 
gado pela Lei n. 7.841/89. A última concessão que ainda vigorava era a dicotomia separação judicial-divórcio, extinta pela Emenda Constitucional n. 66/2010.

Com a vinda da Constituição Federal de 1988 se estabeleceram princípios voltados para o indivíduo, como o da dignidade da pessoa humana e outros, e transpareceu-se a intenção do constituinte de valorar o indivíduo na sociedade moderna, em detrimento do patrimônio, crença ou raça. Nesse sentido, depreende-se que acima de uma situação cultural estabelecida é preciso observar as necessidades do cidadão de hoje, que busca soluções mais céleres e econômicas.

A redação anterior do parágrafo $6^{\circ}$, artigo 226 da Constituição Federal de 1988 dizia: “ $§ 6^{\circ}$ - O casamento civil pode ser dissolvido pelo divórcio, após prévia separação judicial por mais de um ano nos casos expressos em lei, ou comprovada separação de fato por mais de dois anos.” (grifou-se)

Com a alteração, o parágrafo mencionado passou a ter a seguinte redação: "§ $6^{\circ} \mathbf{O}$ casamento civil pode ser dissolvido pelo divórcio.” (grifou-se)

Sendo assim, é possível observar que a alteração ocorreu basicamente com a supressão do requisito para o divórcio, qual seja a separação por um ano quando judicial ou dois quando de fato. Parece clara a alteração que o artigo trouxe, mas, após a sua publicação, muitas questões foram levantadas a respeito da atual existência ou não da separação.

Embora o requisito separação tenha sido excluído do texto constitucional, e atualmente o divórcio possa ser requerido de forma direta, há duas correntes que defendem: (I) a permanência da possibilidade de requerimento da separação e (II) a total inexistência desse instituto.

\section{b) A extinção ou não da}

\section{separação}

Há aqueles que entendem que a função da Emenda Constitucional n. 66 de 2010 seria extinguir a separação judicial e permitir que as pessoas interessadas em se separar possam requerer o divórcio direto, sem a necessidade de um requisito limitador. Mesmo entendimento usado como justificador do Projeto de Emenda Constitucional n. 413/2005, que deu origem à emenda em estudo.

Isso seria um benefício, uma vez que garantiria àqueles que quisessem se separar a liberdade de fazê-lo quando o desejassem, não sendo necessária a manutenção de um vínculo jurídico em que não há mais nenhum vínculo afetivo.

Ressalte-se, por oportuno, que o "vínculo afetivo", assim como mencionado no parágrafo anterior, revela a ideia de que o afeto é modernamente um dos princípios basilares do direi- 
to de família. Portanto, as questões religiosas e de "moral do Estado" estariam sendo superadas pelos laços criados entre os indivíduos de forma mais íntima. O que demonstra a transição histórica dos valores patrimonialistas e centrados no ceio familiar, como conjunto "econômico" ou resultado de uma crença, e sob comando do pai, para um momento em que o centro da atenção é o indivíduo como cidadão pertencente ao Estado, sua unidade importante, e, posteriormente, a família como sua célula base.

De acordo com o relator da PEC 42 de 2008, Senador Demostenes Torres, em notícia veiculada pela Agência Senado:

Todos serão beneficiados com a emenda imediatamente, porque toda lei tem retroatividade ou ulterioridade, ou seja, vai para trás ou à frente, como regra geral - disse o senador. Demostenes ressalvou apenas, como hipótese impeditiva da retroatividade, as situações em que a lei adotada "ferir a coisa julgada, o ato jurídico perfeito ou prejudicar direito adquirido". No caso da lei penal, também não poderia haver retroação para prejudicar o que já tenha sido julgado. No entanto, como obser- vou, não se trata de nenhum desses casos. Pelo contrário, quem deseja se separar está ganhando um benefício, seja de tempo como até mesmo de economia de medidas administrativas ou judiciais, inclusive pagamento de advogados e de despesas cartoriais. ${ }^{65}$

Assim, além do fator "liberdade", outros dois benefícios da emenda, como extintiva da separação, seriam a economia quando da contratação de advogado, nos custos processuais e no que diz respeito ao tempo para a determinação do divórcio. Isso porque, antes, para se separar era necessário entrar com o pedido de separação judicial e, posteriormente, se aguardar o prazo de 1 (um) ano para só então requerer-se o divórcio, ou entrar com o divórcio após 2 (dois) anos da separação de corpos.

O fato é que o tempo do processo não seria bem a expressão exata do tempo dos que desejavam se separar, e esse era um empecilho à felicidade do ex-casal.

Quem defende o fim da separação agrupa toda essa ótica anteriormente citada. É o que entende Maria Berenice Dias ${ }^{66}$ quando afirma que:

65 BRANDÃO, Gorette. Para Demostenes, PEC do Divórcio extingue processos de separação judicial em exame. Senado, Brasília, 13 jul. 2010. Disponível em: <http:// www.senado.gov.br/noticias/verNoticia.aspx?codNoticia=103478\&codAplicativo=2 >. Acesso em: 27 fev. 2011.

66 DIAS, Maria Berenice. Divórcio Já!: comentários à emenda constitucional 66 de 13 de julho de 2010. São Paulo: Editora Revista dos Tribunais, 2010, p. 138. 
Anova ordem constitucional veio para atender ao anseio de todos e espancar definitivamente a identificação da causa da falência do casamento para a sua dissolução. Este certamente foi o grande mérito da reforma: banir a perseguição de culpados pelo fim do amor.

A mesma autora - ora utilizada por tratar-se de expressão mais característica da defesa pelo fim da separação -, prossegue dizendo que, com relação à manutenção da separação, manteriam-se vínculos que não se justificam face à clara intenção do casal de se separar:

Apesar da resistência de alguns, com a aprovação da EC 66/2010, a separação desapareceu do sistema jurídico. Ainda que permaneçam no Código Civil os dispositivos que regiam o instituto (CC 1.571 a 1.578), tal não significa que persista a possibilidade de alguém buscar somente 0 "término" do casamento, quer judicial quer extrajudicialmente. Agora só é possível pleitear a dissolução do casamento via divórcio.

Muitas vezes, quando o casal não desejava o divórcio, até por motivos religiosos, a separação era a saída. Mas este motivo não justificava a mantença de um instituto que foi banido do sistema jurídico pela Constituição. O jeito de atender ao desejo de que não quer se divorciar é fazer uso da separação de corpos, que põe fim aos deveres do casamento, rompe o regime patrimonial, mas mantém hígida a sociedade conjugal. $\mathrm{O}$ pedido pode ser levado a efeito de modo consensual ou por iniciativa de somente um dos cônjuges. Por mútuo acordo não se trata de medida cautelar, mas de procedimento de jurisdição voluntária. Não havendo filhos menores ou incapazes, a separação de corpos pode inclusive ser levada a efeito através de escritura pública. ${ }^{67}$

Nesse sentido, da norma constitucional revogando a infraconstitucional, coaduna-se o entendimento de Paulo Lôbo. ${ }^{68}$

A jurisprudência em sua maioria segue o entendimento de que não há necessidade de separação para decretação do divórcio. É o caso dos Desembargadores Rui Portanova, Roberto Carvalho Fraga. Tais como seguem as ementas:

APELAÇÃO. EMENDA CONSTITUCIONAL N. ${ }^{\circ}$ 66. DIVÓRCIO. Pela entrada em vigor da Emenda Constitucional n. ${ }^{\circ}$ 66, não há mais necessidade de prévia separação ou decurso de prazo para a decretação do divórcio direto. Precedentes jurisprudenciais. APELO PROVIDO. EM MONOCRÁTICA. (Apelação

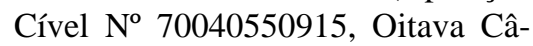

67 DIAS, Maria Berenice. Divórcio Já!: comentários à emenda constitucional 66 de 13 de julho de 2010. São Paulo: Editora Revista dos Tribunais, 2010, p. 129. 68 LÔBO, Paulo. Direito civil: famílias. 4. ed. São Paulo: Saraiva, 2011, p. 164. 
mara Cível, Tribunal de Justiça do RS, Relator: Rui Portanova, Julgado em 10/05/2011.) (grifou-se.)

AGRAVO DE INSTRUMENTO. FAMÍLIA. SEPARAÇÃO CONSENSUAL. ALTERAÇÃO PARA DIVÓRCIO DIRETO. APLICAÇÃO IMEDIATA DA EMENDA CONSTITUCIONAL $\mathrm{N}^{\circ} \quad 66 / 2010$. POSSIBILIDADE. NORMA DE EFICÁCIA PLENA E IMEDIATA, SENDO DESNECESSÁRIA REGULAMENTAÇÃO POR LEGISLAÇÃO INFRACONSTITUCIONAL. AGRAVO PROVIDO, POR MAIORIA. (Agravo de Instrumento No 70039741319, Sétima Câmara Cível, Tribunal de Justiça do RS, Relator: Roberto Carvalho Fraga, Julgado em 27/04/2011.) (grifou-se)

Em referência aos mesmos precedentes destaco os seguintes trechos:

Interpretação diversa resultaria na inafastável conclusão de que a Emenda Constitucional n. ${ }^{\circ} 66$ é uma inteira inutilidade.

[...] De qualquer forma, para além de divergências na interpretação da regulamentação da matéria, penso que em casos como o presente é preciso adotar uma posição um tanto mais pragmática.

[...] A prática (inclusive extrajudicial) já está em vias de consolidar a possibilidade de divórcio, sem prévia separação e sem comprovação do decurso de qualquer prazo. (Apelação Cível N No 70040550915, Oitava Câmara Cível, Tribunal de Justiça do RS, Relator: Rui Portanova, Julgado em 10/05/2011.) (grifou-se)
A referida regra constitucional tem eficácia plena e imediata, uma vez que em seu texto não ficou estabelecida qualquer ressalva que pudesse remeter à regulamentação por legislação infraconstitucional. Assim, percebe-se que a nova regra veio para atender aos anseios da população, fazendo com que as normas jurídicas passem a caminhar junto e incidir diretamente nos fatos cotidianos, acompanhando as relações interpessoais e a vontade de seus destinatários.

[...] Tenho que - com o maior respeito a posições em contrário - o direito de família e os julgamentos nesta seara têm por escopo aproximar o cidadão do direito (e viceversa), para de uma forma rápida e eficaz trazer a tão esperada resposta e definição jurisdicional.

Em consequência deste novel entendimento, restarão agilizadas as demandas processuais, tornando mais céleres e menos onerosos os processos que aportam no Poder Judiciário. E, mais, dar-se-á uma definição mais imediata e célere àqueles que chegam ao direito de família, requerendo auxílio e definições incontinenti. (Agravo de Instrumento $\mathrm{N}^{\mathrm{o}} 70039741319$, Sétima Câmara Cível, Tribunal de Justiça do RS, Relator: Roberto Carvalho Fraga, Julgado em 27/04/2011.) (grifou-se)

Ocorre que com relação ao precedente do Desembargador Roberto Carvalho Fraga, é importante destacar que o mesmo compreende que:

[...] Com efeito, cumpre gizar, primeiramente, que a questão posta no 
presente recurso, data máxima venia, não reclama acurado estudo de hermêutica para a devida compreensão do alcance da Emenda Constitucional $n^{\circ} 66$ de 13 de julho de 2010. É que, a Emenda Constitucional $n^{\circ} 66$ limitou-se a admitir a possibilidade de concessão de divórcio direto para dissolver o casamento, afastando a exigência, no plano constitucional, da prévia separação judicial e do requisito temporal de separação fática. E não foi além disso.

Portanto, é forçoso convir que essa disposição constitucional evidentemente não retirou do ordenamento jurídico a legislação infraconstitucional que continua regulando tanto a dissolução do casamento como da sociedade conjugal e estabelecendo limites e condições, permanecendo em vigor todas as disposições legais que regulamentam a separação judicial, como sendo a única modalidade legal de extinção da sociedade conjugal, que não afeta o vínculo matrimonial. [...] (Agravo de Instrumento $\mathrm{N}^{\circ}$ 70039741319, Sétima Câmara Cível, Tribunal de Justiça do RS, Relator: Roberto Carvalho Fraga, Julgado em 27/04/2011). (grifou-se)

Nesse sentido, o precedente acima tem diferencial do entendimento da Dra. Maria Berenice Dias ${ }^{69}$, pois essa entende que a separação judicial não mais existe (embora seja possível a separação de corpos), e aquele entende que ainda persiste a separação judicial no ordenamento jurídico.

Por outro lado, existem aqueles que entendem que a nova redação do $\S 6^{\circ}$ do art. 226 da CF não alterou as disposições do Código Civil, sendo ela ainda um requisito para o divórcio, conforme o pensamento do Desembargador Luiz Felipe Brasil dos Santos: ${ }^{70}$

Em conclusão - embora admita que a linha de pensamento que sustento representa uma visão "politicamente incorreta", em um tempo em que a versão midiática, até do direito, tende a preponderar - penso que, por não haver qualquer incompatibilidade entre o novo texto do $\S 6^{\circ}$ do art. 226 da Constituição Federal e os dispositivos correspondentes do Código Civil, estes últimos subsistem em sua inteireza, até que sejam objeto de modificação por lei específica.

Fique claro, porém que esta opinião não significa que me posicione ideologicamente contrário à evolução que se pretendeu com a Emenda Constitucional em foco, mas apenas

69 DIAS, Maria Berenice. Manual de direito das famílias. 7. ed. rev., atual. e ampl.. São Paulo: Editora Revista dos Tribunais, 2010, p. 129.

70 SANTOS, Luiz Felipe Brasil. Emenda Constitucional 66: uma leitura "politicamente incorreta”. In: . Família contemporânea: uma visão interdisciplinar. Coordenação de Ivone M. Candido Coelho de Souza. Porto Alegre: IBDFAM: Letra\&Vida, 2011, p. 241. 
que não aceito - só por ser favorável à tese - que sejam atropeladas regras comezinhas de interpretação do Direito. (grifou-se.)

O mencionado Desembargador ainda afirma que seu entendimento também se funda sob o amparo da Lei de Introdução ao Código Civil, que no seu art. $2^{\circ}$ dispõem que "a lei posterior revoga a anterior quando expressamente o declare, quando seja com ela incompatível ou quando regule inteiramente a matéria que tratava a lei anterior" ${ }^{71}$

Nota-se, ainda, que apesar de divergirem os entendimentos a respeito, na prática tem se aceitado a emenda como aplicável de pronto no âmbito do Rio Grande do Sul. Mesmo assim, é importante levantar tal discussão, a fim de aplicar-se aquilo que está de acordo e que melhor atende à sociedade.

\section{CONSIDERAÇÕES FINAIS}

O grande sonho de se casar envolve uma consciência muito grande de limites e de possibilidades. O ideal de uma vida em conjunto e para sempre é almejado por todos que se propõem a uma vida em comum, mas nem sempre é a realidade. Ocorre que poucos sabem como ocorre a separação e o divórcio, e isso cria alguns impasses quando se é preciso efetivá-los.

Talvez porque o sistema divorcista, recente, de 1977, tenha vindo com o requisito separação, muitas pessoas apenas se davam conta do processo de separação quando entravam com o pedido na Justiça e assim mesmo nem sempre conseguiam compreender que para o fim do vínculo ainda era necessário transformar a separação em divórcio. E isso ocorre até hoje, como se pode perceber ao se trabalhar com população de baixa renda. Por vezes, eles entendem que o simples pedido de separação já os desvincula do antigo cônjuge, nem mesmo vão ao cartório homologar a sentença, quanto mais retornar para requerer a conversão em divórcio. É claro que não é uma regra, mas casos assim existem.

A descoberta, após anos, de que não se pode casar novamente em face a não homologação do divórcio, causa certa frustração, mais um processo, mais uma etapa ressuscitando uma dor.

A evolução do direito de família fez com que o legislador percebesse a necessidade de se simplificar o processo de ruptura conjugal com a

71 SANTOS, Luiz Felipe Brasil. Emenda Constitucional 66: uma leitura "politicamente incorreta”. In: . Família contemporânea: uma visão interdisciplinar. Coordenação de Ivone M. Candido Coelho de Souza. Porto Alegre: IBDFAM: Letra\&Vida, 2011, p. 239. 
retirada do requisito separação para a concessão do divórcio. A grande questão é que o requisito foi retirado, mas o instituto não foi extinto. De certo modo, isso não é um prejuízo, pelo contrário, seria manter um direito aos cidadãos, o de poder optar por requerer diretamente o divórcio ou simplesmente a separação, findando simplesmente a sociedade conjugal. Porém, os tribunais, segundo a justificativa rasa do projeto de emenda que originou a Emenda Constitucional $n$. $66 / 2010$, optaram por não mais conceder a separação. Não estariam eles restringindo direito arbitrariamente? A discussão não é finda, mas o assunto parece que será relegado ao esquecimento com o passar do tempo. Talvez pela objetividade demandada pelos dias de hoje, ou pelo comodismo de se fazer o que parece mais fácil, que é deixar um instituto cair no desuso e, portanto, no esquecimento.

É pertinente ressaltar trecho de Sílvio de Salvo Venosa, sobre o qual faz-se a reflexão de que, talvez com tantas discussões, o mais acertado seria, enquanto não se alteram as disposições do Código Civil, conferir ao casal, pretenso a se separar, a escolha por pedir a separação e se submeter aos prazos e determinações legais, ou diretamente o divórcio, a fim de finalizar de vez a relação:
Salientemos que se estiverem presentes os pressupostos tanto da separação quanto do divórcio (separação de fato por mais de dois anos), os cônjuges tinham a faculdade de escolher por uma ou outra saída jurídica para o desenlace de seu matrimônio. É claro que, na prática, falido o casamento, propendia na maioria das vezes para o divórcio direto, mas tal não significava que não pudessem persistir para alguns o interesse pela separação, a qual propiciava a retomada do casamento no futuro após maior meditação. Nesse ponto, deve-se atentar para o novo sistema. Decretado o divórcio, de houver reconciliação, somente com novo casamento poderão novamente se unir legalmente os cônjuges. De outra face, com a separação de fato por mais de dois anos era possível o pedido de divórcio direto, provando-se simplesmente esse lapso temporal. ${ }^{72}$

Por outro aspecto, o término do vínculo pela morte apenas causa estranheza quando se questiona a questão do ausente que tem sua morte presumida decretada. O novo casamento do cônjuge que fica deve valer ainda que o ausente retorne? O que fazer com uma vida que recomeça e com aquela que ressurge? Não há uma resposta diferente do que a de que é preciso de fato respeitar a individualidade e privacidade dos envolvidos, só eles sabem os motivos para se manter uma relação. Caberia a ambos sentar e

72 VENOSA, Sílvio de Salvo. Direito civil: direito de família. 11. ed. v. 6. São Paulo: Atlas, 2011, p. 164. 
discutir o que fazer. O Estado tem se envolvido em questões de direito de família, porque é seu papel garantir os direitos fundamentais dos cidadãos, mas até que ponto isso é saudável?
Muito mais do que respostas, esta conclusão almeja introduzir um assunto e provocar a discussão, tão salutar para a efetivação de um processo de justiça.

\section{REFERÊNCIAS}

BRANDÃO, Gorette. Para Demostenes, PEC do Divórcio extingue processos de separação judicial em exame. Senado, Brasília, 13 jul. 2010. Disponível em: <http:// www.senado.gov.br/noticias/ verNoticia.aspx?codNoticia $=103$ 478\&codAplicativo $=2>$. Acesso em: 27 fev. 2011.

BRASIL. Código Civil de 1916 - Lei n. 3.071, de $1^{\circ}$ de janeiro de 1916. Diário Oficial da União, Poder Executivo, Rio de Janeiro, RJ, 05 jan. 1916. Disponível em: <http:// www.planalto.gov.br/ccivil_03/ leis/L3071impressao.htm>. Acesso em: 18 out. 2011.

Constituições Anteriores de 1824 a 1967 EMC n. 1 de 1969. Diário Oficial [da] República Federativa do Brasil, Poder Executivo, Brasília, DF. Disponível em: <http://www4. planalto.gov.br/legislacao/ legislacao-historica/constituicoesanteriores-1\#content>. Acesso em: 23 abr. 2011.
Emenda Constitucional n. 66. Diário Oficial [da] República Federativa do Brasil, Poder Executivo, Brasília, DF, 13 jul. 2010. Disponível em: <http://www.planalto.gov.br/ccivil_03/constituicao/emendas/emc/emc66.htm>. Acesso em: 17 fev. 2011. . Projeto de Emenda Constitucional n. 413/2005. Diário Oficial da União, Poder Executivo, Brasília, DF, 15 jun. 2005. Disponível em: <http://www.camara.gov. br/sileg/integras/315665.pdf $>$. Acesso em: 23 mai. 2011. . RT MiniCódigos - Código Civil, Código de Processo Civil, Código Comercial, Constituição $\mathrm{Fe}$ deral, Legislação civil, processual civil e empresarial. Organização: Yussif Said Cahali. 13. ed. rev., ampl. e atual. São Paulo: Revista dos Tribunais, 2011.

- Tribunal de Justiça do Rio Grande do Sul. Apelação Cível n. 70040550915 - RS. Apelante: D.O.S. Apelado: A.P.S.S. Relator: 
Rui Portanova, Porto Alegre, RS, 10 de maio de 2011. Disponível em: <http://www1.tjrs.jus.br/bus $\mathrm{ca} /$ ?q=70040550915\&tb=jurisno va\&pesq=ementario\&partialfield $\mathrm{s}=\% 28 \mathrm{TipoDecisao} \% 3 \mathrm{Aac} \% 25 \mathrm{C}$ 3\%25B3rd\%25C3\%25A3o|Tipo Decisao\%3Amonocr\%25C3\%25 A1tica $\% 29 \&$ requiredfields $=\& a$ a q=>. Acesso em: 23 mai. 2011. - Tribunal de Justiça do Rio Grande do Sul. Agravo de Instrumento n. 70039741319 RS. Apelante: J.M.S. Apelado: A.J. Relator: Roberto Carvalho Fraga, Porto Alegre, RS, 27 de abril de 2011. Disponível em: $<$ http://www1.tjrs.jus.br/busca/? $\mathrm{q}=70039741319 \& \mathrm{tb}=\mathrm{jurisnova} \&$ pesq $=$ ementario $\&$ partialfields $=\%$ 28TipoDecisao\%3Aac\%25C3\%2 5B3rd\%25C3\%25A3o|TipoDecis ao\%3Amonocr\%25C3\%25A1tic a $\% 29 \&$ requiredfields $=\&$ as_q $=>$. Acesso em: 23 mai. 2011.

CARVALHO NETO, Inacio de. Separação e divórcio: teoria e prática. 10. ed. Curitiba: Juruá, 2009.

CHAVES, Luís Cláudio da Silva. A separação de fato e seus efeitos. Domtotal.com, Belo Horizonte, 26 ago. 2009. Disponível em: $<$ http://www.domtotal.com/ colunas/detalhes.php?artId=903 >. Acesso em: 08 dez. 2011.

DIAS, Maria Berenice. Divórcio Já!: comentários à emenda constitu- cional 66 de 13 de julho de 2010. São Paulo: Editora Revista dos Tribunais, 2010.

Manual de direito das famílias. 7. ed. rev., atual. e ampl.. São Paulo: Editora Revista dos Tribunais, 2010.

DINIZ, Maria Helena. Curso de direito civil brasileiro: direito de família. 25. ed. v. 5. São Paulo: Saraiva, 2010.

LÔBO, Paulo. Direito civil: famílias. 4. ed. São Paulo: Saraiva, 2011.

NADER, Paulo. Curso de direito civil: direito de família. v. 5 . Rio de Janeiro: Forense, 2006.

PONTES DE MIRANDA. Tratado de direito de família. v. 1. Atualizado por Vilson Rodrigues Alves. Campinas: Bookseller, 2001.

RODRIGUES, Sílvio. Direito civil: direito de família. v. 6. 27. ed. atual. Por Francisco José Cahali, com anotações ao novo Código Civil (Lei n. 10. 406, de 10-1, 2002). São Paulo: Saraiva, 2002.

Direito civil: direito de família. v. 6.28 ed. rev. e atual. por Francisco José Cahali, de acordo com o novo Código Civil (Lei n. 10.406, de 10/01/2002). São Paulo: Saraiva, 2008.

SANTOS, Luiz Felipe Brasil. Emenda Constitucional 66: uma leitura "politicamente incorreta". In: . Família contemporânea: uma visão interdisciplinar. Coordenação de Ivone M. Candido 
Coelho de Souza. Porto Alegre: IBDFAM: Letra\&Vida, 2011, p. 235-241. SEPARAÇÃO. In: MICHAELIS Moderno Dicionário da Língua Portuguesa. São Paulo: Melhoramentos, 1998. Disponível em: <http://michaelis.uol.com. br/moderno/portugues/index. php?lingua=portugues-portugue
s\&palavra=separa\%E7\%E3o>. Acesso em: 05 dez. 2011. SPENGLER, Fabiana Marion; SPENGLER NETO, Theobaldo. Inovações em direito e processo de família. Porto Alegre: Livraria do Advogado, 2004.

VENOSA, Sílvio de Salvo. Direito civil: direito de família. 11. ed. v. 6. São Paulo: Atlas, 2011. 